\title{
Empire of Riches: Visions of Dutch Commercial Imperialism, c. 1600-1750
}

\author{
Arthur Weststeijn
}

If there was anything exceptional about the early-modern Dutch empire, it was that the Dutch, unlike any other global power in the earlymodern world, lived in a Republic. All European competitors who contended with the Dutch worldwide throughout the seventeenth and eighteenth centuries, be they Portuguese, Spanish, English, French, Danish or Swedish, were subjects of monarchical states. Single rulers also governed all non-European imperial powers, from the Ottoman sultanate to the Tokugawa shogunate and from the Mughal empire to the Ashanti empire. This monarchical dominance forms a clear contrast with Dutch imperialism, which took wing on the very moment the Dutch Republic came into being in the late sixteenth century as a confederate, kingless state. Indeed, the subsequent development of Dutch colonial rule in the first half of the seventeenth century was essentially justified as an anti-imperial project to undermine claims for Habsburg universal monarchy. Dutch colonial expansion, its propagandists argued, protected liberty against tyranny worldwide. ${ }^{1}$

\footnotetext{
A. Weststeijn $(\bowtie)$

Utrecht University, Utrecht, The Netherlands

e-mail: a.v.weststeijn@uu.nl

(C) The Author(s) 2019

R. Koekkoek et al. (eds.), The Dutch Empire between Ideas and Practice, 1600-2000, Cambridge Imperial and Post-Colonial Studies Series, https://doi.org/10.1007/978-3-030-27516-7_3
} 
In actual colonial practice, the 'republican' dimension of the Dutch empire made little difference, for Dutch imperialism clearly shared many characteristics with other imperial states - not least, as Catia Antunes has shown, with the Spanish and Portuguese empires. ${ }^{2}$ Yet on the more abstract level of intellectual history, Dutch imperial self-justification in terms of a global competition between liberty and tyranny has more significance, for it reveals the conceptual opposition between republicanism, commonly defined as a language of liberty in the sense of non-domination, and imperialism as a language of domination. ${ }^{3}$ Indeed, the Dutch Republic, despite being one of Europe's most expansionist and belligerent policies, never in its history called itself an empire. Unlike the conceptual and ideological construction of, for example, the 'British Empire' over the seventeenth and eighteenth centuries, there was no intellectual development of a clear-cut 'Dutch empire'. ${ }^{4}$

How to account for this absence of imperial self-awareness in early-modern Dutch history? This chapter argues that the tension between republican liberty and imperial domination resulted in a particular commercial interpretation of empire that was developed from the very onset of Dutch imperialism around 1600 onwards. ${ }^{5}$ In this process, the actual practice of Dutch colonial rule overseas, based on conquest, occupation and regal display, was mitigated through metropolitan representations that proclaimed its beneficial nature as a 'republican empire' of worldwide commercial cooperation and prosperity. ${ }^{6}$ The ideological construction of this 'empire of riches', I argue, can be considered a counternarrative to the 'embarrassment of riches' that Simon Schama famously characterized as a foundational aspect of Dutch culture. ${ }^{7}$ For Dutch imperial advocates in the seventeenth and eighteenth centuries, worldly riches were not just a reason for embarrassment but rather for self-confidence: global trade was considered to be the foundational principle of a republican empire that merged commercial self-interest with the res publica, the common good of the commonwealth and, by extension, of humanity.

To explore the development of this republican-imperial narrative, I focus on a number of case studies of moral and cultural framing of empire within early-modern Dutch society, building upon insights on the significance of humanist high culture in the early-modern Spanish and British empires, ${ }^{8}$ and on scholarship regarding the imperial dimension of nineteenth- and twentieth-century metropolitan cultures. ${ }^{9}$ This focus on the metropolitan context of the Dutch empire does not imply 
a strictly 'national' approach, for local as well as international contexts and actors interacted in the creation of early-modern Dutch visions of empire. Indeed, the analysis of these visions reveals how a national conception of 'Dutch empire' did not materialize because of the persistent notion of a purely commercial enterprise based upon urban and corporate personifications of empire. This imperial self-presentation in terms of a Company-Republic may have been typical for the Dutch context, but this does not warrant the conclusion that the Dutch republican framing of commercial empire was altogether exceptional. A comparable emphasis on commerce pervaded seventeenth- and eighteenth-century visions of empire in Britain, ${ }^{10}$ while the republican empire of the United States of America has also tried to solve the tension between liberty and domination by 'hiding' its imperial nature. ${ }^{11}$ The Dutch case is relevant precisely because it shows how an alternative idea of empire in terms of global commercial exchange for the sake of profit developed and why this idea remains in vogue in a postcolonial world.

\section{Ciceronian Ethics and the Intellectual Origins of Dutch Commercial Imperialism}

In the summer of 1601, Sa'id al-Din, the sultan of Ternate in the Moluccas, received a remarkable letter from the other side of the globe. The parchment letter was written in elegant Arabic, but the signature and red lacquer seal attached to it revealed it came from an unlikely source: Maurice, Prince of Orange, the military leader of the Dutch Republic. A small Dutch delegation had recently arrived at Ternate and delivered the letter to the sultan with the following request:

Since we have considered that it is not only honourable, but also expedient for our Republic that we not only maintain love and peace with our neighbours, but also establish friendship and conclude treaties to the extent of our abilities with foreign nations and distant peoples, and [having considered] that the people of our lands, driven by natural inclination, are desirous to travel abroad and see far-flung countries, we have seen fit to facilitate their endeavour and fulfil their ardent desire and to grant them an opportunity by concluding and confirming a mutual covenant and treaty with the inhabitants of those parts. ${ }^{12}$

For Sa'id al-Din, this was an offer he could not refuse. The sultan regarded the Dutch as useful allies in the ongoing competition with 
the neighbouring island of Tidore, which was controlled by their common enemy, the Portuguese. Having read the Arabic letter, he therefore granted the Dutch permission to launch an attack against the Portuguese fortress on Tidore.

At first sight, this particular diplomatic episode was not exceptional, and it also had no significant consequences on the ground (the attack against the fortress on Tidore failed miserably). In the years around 1600 , there were numerous comparable cases of collaboration between local sovereigns in Southeast Asia and Dutch interlopers who tried to outplay the Portuguese overseas. ${ }^{13}$ Indeed, two years before, sultan Sa'id al-Din had sent a royal letter of his own to the Prince of Orange, together with a gift of cloves to show his willingness to cooperate. ${ }^{14}$ This particular instance of global diplomacy between rulers in Southeast Asia and the Dutch Republic was therefore not surprising. More significant is the specific wording of the Arabic letter, which exemplifies how the Dutch thought of themselves and presented themselves on this global diplomatic stage. At its very inception, Dutch colonialism appropriated the venerable language of Ciceronian ethics to legitimize its republican imperial endeavour.

The crucial passage of the Arabic letter concerns the phrase 'not only honourable, but also expedient'. This may seem a fairly general statement of little significance, but it gains weight considering that the author of the letter was the French scholar Joseph Justus Scaliger, professor at Leiden University and arguably the most prominent humanist in Europe around 1600. ${ }^{15}$ Scaliger had been requested to make the Arabic text on behalf of the Old East India Company (Oude Compagnie), one of the first Dutch companies for colonial trade. The letter, signed and sealed by the Prince of Orange, was evidently meant to gain the confidence of sovereign rulers in Southeast Asia and to show the good intentions of the naval expedition organized by the Company. To address its intended audience, the Company made a Portuguese as well as an Arabic version of the letter, since Portuguese and Arabic were used regularly in international communication in Southeast Asia. There was only one man in the Dutch Republic up to the task of making the Arabic text, and that man was Scaliger.

True to his nature and fame as a humanist scholar deeply steeped into the classical tradition, Scaliger clearly regarded the task as an opportunity to put Europe's classical vocabulary into a time-honoured, exotic language (Scaliger was a self-taught Arabist and had never met a native 
speaker of Arabic). To accomplish his aims, he had at his disposal an earlier Arabic patent letter made for the first Dutch voyage to the East Indies in $1595,{ }^{16}$ as well as his own handwritten Arabic-Latin lexicon. This lexicon provides the clue for Scaliger's understanding of the Dutch colonial expedition, which set sail some four weeks after he finished the letter on 1 June 1600. The lexicon shows that the Arabic phrasing Scaliger used for 'honourable' (hasan) and 'expedient' (nafi') is based on his Arabic translations of two key Latin terms: honestum and utile. ${ }^{17}$

Given Scaliger's humanist credentials, the source of the coupling of these two terms is obvious: it derives from Cicero's De officiis, the dominant classical handbook on ethics in European humanism. Discussing the potential conflict between morality and utility, Cicero famously claimed the two are inseparable: that which is morally right, or honourable (bonestum), is also expedient (utile), and vice versa. ${ }^{18}$ In the light of this classical framework, Scaliger's prominent coupling of honourable and expedient at the very start of the Arabic letter therefore has a significant connotation: it is meant to present Dutch interloping in Southeast Asia as a token of Ciceronian ethics.

The significance of Scaliger's statement is further corroborated by the frequency with which the same terms were used in humanist circles and discussions about colonial trade in the Dutch Republic around 1600. A crucial role in this regard was played by Dirck Coornhert, a towering figure in early Dutch humanism who had translated Cicero's De officiis into Dutch in 1561. ${ }^{19}$ In his moralistic dialogue The Merchant (De coopman) from 1580, Coornhert argued that a honourable merchant engages in expedient trade. ${ }^{20}$ Once Dutch colonial trade took off towards the end of the sixteenth century, the Ciceronian language that Coornhert had made popular gained momentum. From 1594 onwards, many different companies for overseas trade were established; when the States of Holland advised in 1601 to merge them together, they argued this united company 'would not only be honourable and expedient but necessary for the conservation of trade'. ${ }^{21}$ To maintain internal concord and to outdo external competition (embodied in 1600 by the foundation of the English East India Company), it was deemed necessary to bring a variety of commercial interests together under a single organization which, consisting of different chambers in different cities, mirrored the confederal political structure of the Dutch Republic. ${ }^{22}$

The subsequent establishment in 1602 of the United East India Company (Vereenigde Oost-Indische Compagnie, or VOC) followed this 
logic. In the process, the dominant figure in the creation of the VOC, the statesman Johan van Oldenbarnevelt, added a significant third term to the Ciceronian equation. Explaining the reasons why the VOC should be granted an exclusive charter by the Dutch States General, he claimed that this would be 'honourable, expedient and profitable'. ${ }^{23}$ Van Oldenbarnevelt thus tried to explicate Cicero's ambiguous language for a commerce-minded audience, merging the classical vocabulary of honestum and utile with a modern emphasis on straightforward profit. The strategy worked, and this tripartite explanation of Ciceronian ethics ended up prominently in the preamble of the official charter granted to the VOC in 1602:

It would not only be honourable, expedient and profitable for the United Provinces, but also for all who had commenced and participated in this commendable trade, if the Company is united and commerce is shared, managed and expanded under a fixed and secure unity, order and governance, for all the residents of the United Provinces who would like to participate in it. ${ }^{24}$

The VOC charter thus connected the self-interest of a private company to the common interest of the nascent Dutch Republic.

The prominence of the Ciceronian theme in the intellectual origins of Dutch commercial imperialism is made manifest in the work of Hugo Grotius, Scaliger's star student at Leiden, close collaborator of Van Oldenbarnevelt and legal adviser to the recently founded VOC. In his manuscript treatise De jure praedae, commissioned by the VOC to justify the seizure of a Portuguese vessel in the Strait of Singapore, Grotius argued with intricate humanist reasoning that the Dutch act of piracy had been honestum as well as utile. ${ }^{25}$ Moreover, Grotius followed Scaliger's lead in presenting Dutch colonial trade as the embodiment of global commercial cooperation. While Scaliger's Arabic letter from 1600 manifestly employed terms such as love, peace, friendship and treaty to present Dutch interloping in Southeast Asia as a benign enterprise based on mutual collaboration, Grotius continued with the claim that colonial trade fulfilled the purpose of interhuman interaction: 'A natural bent (so to speak) for maritime enterprise characterizes our people, who regard it as the most agreeable of all occupations to aid humanity, while finding a ready means of self-support, through an international exchange of benefits from which no one suffers loss'. ${ }^{26}$ In this way, Grotius combined 
the construction of a republican Dutch identity based on maritime commerce with the ideal of a global exchange of commodities sanctioned by natural law. Dutch self-interest (which, for Grotius, primarily entailed the interest of the province of Holland) was ideologically coupled to the general interest of humanity at large.

The dominance of humanist reasoning around 1600 meant that the construction of this commercial republican identity was firmly based upon a classical model: that of the Batavians, the ancient tribe that allegedly had remained independent from the Roman Empire. Originally, this 'Batavian myth' had clear anti-imperial overtones, being employed not only as a token of an intrinsic Dutch freedom from domination (in its Roman and Habsburg guises), but also as a token of agrarian simplicity, unstained by commercial expansion and the resulting wealth. ${ }^{27}$ Grotius, however, gave an important twist to this traditional view by presenting the Dutch as a seafaring people who explored the outer confines of the globe to seek for 'honourable profit'. This commercial ambition, Grotius argued, was the opposite of territorial imperialism. With a curious linguistic explanation that typified his humanist approach, Grotius stated that it could not be a coincidence that the Dutch term for imperium, 'rijk', is also the Dutch word for 'rich'. ${ }^{28}$ In other words, the nascent Dutch empire should not be interpreted as a standard expansionist empire, but as something different: an empire of riches.

\section{Empire Abroad vs. Empire at Home: Batavia, Amsterdam AND THE Imperial Metropolis}

In 1619, the humanist interpretation of empire that permeated Dutch culture at the start of the seventeenth century was materialized in concrete colonial practice with the creation of Batavia, the centre of the Dutch empire in Asia. The new city, raised upon the ruins of Jayakarta, was baptized on the explicit instigation of the governing board of the VOC as a physical incarnation of the Batavian myth. This manoeuvre however could not conceal the deep rift between the intellectual construction of empire and its actual manifestation on the ground. Clearly, the alleged opposition between a territorial empire based on warfare and conquest and a commercial empire based on peace and trade did not correspond to colonial reality. The VOC frequently engaged in open warfare, not only against its European competitors but also against 
erstwhile allies in Southeast Asia, the genocide on the Banda Islands in 1621 being the most striking example. Indeed, the perpetrator of this genocide, VOC governor-general Jan Pieterszoon Coen, effectively collapsed the distinction between bellicose and commercial imperialism with his famous dictum: 'Trade without war or war without trade cannot be maintained'. ${ }^{29}$

Tellingly, the Amsterdam chamber reacted to Coen's aggressive policies in Southeast Asia with the claim that from their commercial point of view, honourable behaviour does not consist in 'exercising violence and injustice' but in 'making profit'-an insight, they stated, 'princes and potentates' did not understand. ${ }^{30}$ Profitability was thus considered as the essence of a republican, non-monarchical morality. In the traditional Ciceronian balance between honestum and utile, the emphasis had been shifted towards expedience in sheer commercial terms of profitability. A comparable development of a commercial ideology of colonization took place in contemporary England, although the conceptual prominence of 'profit' in the Dutch context slightly differed from English discussions in terms of 'greatness'. While English colonial writers and actors such as Robert Johnson primarily discussed commercial wealth in the context of the formation of (monarchical) state power, Dutch visions focused upon the mercantile interests of the VOC as a corporate organization intertwined with the confederal Dutch body politic, a CompanyRepublic. $^{31}$ The resulting embrace of profit could also be legitimized religiously, for example in the work of the businessman-pamphleteer Willem Usselincx or the Calvinist cleric Godefridus Udemans, who argued that commercial expansion should not be seen as an end in itself but rather as a means to spread the Protestant faith over the globe: profit then counted as the proof of missionary zeal. ${ }^{32}$ 'Gain and godliness', in the felicitous phrasing of Charles Boxer, thus came together in Dutch visions of commercial empire. ${ }^{33}$

Dutch colonial practice overseas, however, followed a trajectory that contrasted with the republican and commercial self-image constructed in the metropolis. As Scaliger's Arabic letter already made clear, the opening moves of Dutch colonial expansion in Asia merged a republican with a monarchical self-presentation, especially centred upon the Prince of Orange as alleged sovereign ruler. To enhance their standing and diplomatic leverage, Dutch delegations in Asia claimed they represented a (non-existing) 'king of Holland'. Seeking to impress Asian sovereigns, they tried to make clear they served a powerful military sovereign, for 
example in 1602 when they gave the Sinhalese king Vimaladharmasuriya a portrait of Prince Maurice on horseback on the battlefield. ${ }^{34}$ This regal self-presentation further increased after the foundation of Batavia, which strengthened the sovereign claims of the VOC itself and especially of its governor-general. The building of a large fortress at Batavia, which housed the residence of the governor-general and the governmental offices of the Council of the Indies, clearly meant to enhance the imperial posture of the VOC and its officials. As eighteenth-century observers noted, the governor-general was 'provided with no less Pomp and State than the Princes of Europe', becoming known as 'the Raya de Jaccatra of the Hollanders, that is the King of Jaccatra'. Rulers throughout the Indian Ocean basin, from Abyssinia to Tonkin, addressed their diplomatic correspondence to the 'king of Batavia'. ${ }^{35}$

The clear-cut imperial nature of Dutch colonialism became manifest as well in the Atlantic. After the creation of the West India Company (WIC) in 1621, a 'grand design' of open warfare and territorial conquest was developed to deal a decisive blow against the Habsburg empire in the Americas. ${ }^{36}$ The occupation of Northeastern Brazil from 1630 onwards in particular revealed the imperial features of Dutch colonialism, not least because Dutch military exploits received intense coverage in contemporary news media. ${ }^{37}$ The presence on Brazilian ground of a scion of the House of Orange, Johan Maurits van Nassau Siegen, and his princely court at Recife between 1636 and 1644, further intensified the regal character of Dutch colonial rule in the Atlantic.

While the Dutch empire thus turned increasingly imperial in the colonial arena, its self-presentation 'at home' continued the creed of commerce and collaboration that had been created around 1600. The lasting dominance of this humanist perspective is especially clear in Amsterdam. The city's dominant role in Dutch colonial expansion was first celebrated shortly after the establishment of the VOC, when the burgomasters of the city commissioned a celebratory decoration of Amsterdam as Ruler of the World (Image 3.1). The image, painted in 1606 upon the lid of a harpsichord played at formal events, portrays Amsterdam in a classical Roman pose as empress of the globe, overlooking the continents, 'places on earth of which even the Ancients had no knowledge', as the accompanying text proudly proclaims. ${ }^{38}$ This self-confidence, a typical gesture of humanist rivalry with the classics that was also manifest in the contemporary works of Grotius, grew even more obvious in later decades, until being immortalized in the very heart of the city. In the imperial 


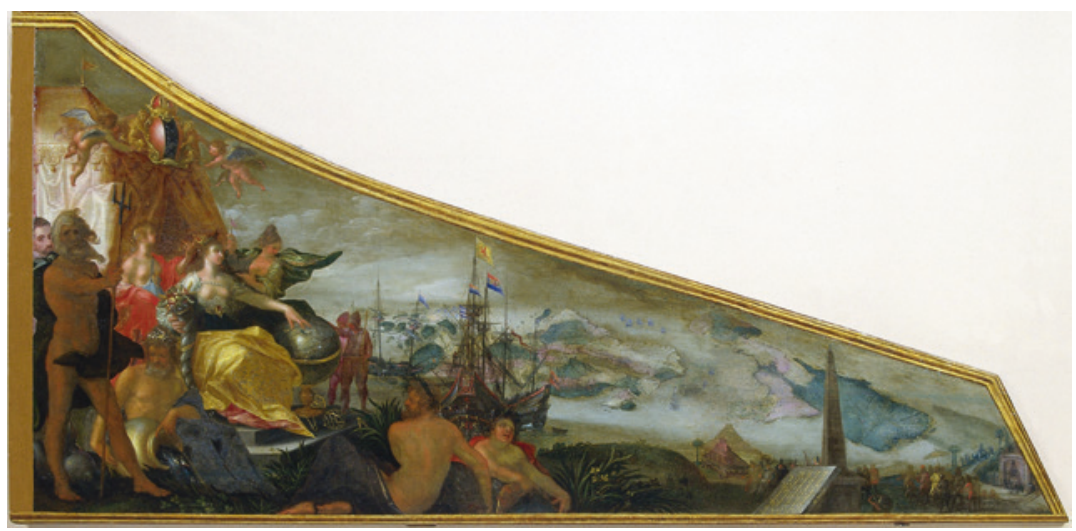

Image 3.1 Pieter Isaacsz, Amsterdam as the Centre of World Trade. Harpsichord Lid showing an Allegory of Amsterdam as the Center of World Trade, c. 1604-1607. Rijksmuseum, Amsterdam

imagination that Amsterdam projected upon itself and the world, the narrative of a benign commercial empire took centre stage. ${ }^{39}$

A crucial moment in the development of this narrative was the visit of Maria de' Medici to the Dutch Republic in 1638. To celebrate its own importance, Amsterdam welcomed the French Queen Mother with a ceremonial royal entry that highlighted the city's central role in global trade. Under the guidance of P.C. Hooft and Caspar Barlaeus, two of the leading humanist authors of the day, an elaborate iconographical programme was designed with large displays and festivities. ${ }^{40}$ The overall theme of the program became manifest upon the queen's entrance to the city at Dam Square, where a monumental triumphal arch was erected, crowned with a large cog, the ship of Amsterdam's coat of arms. As Barlaeus explained in the text he wrote for the occasion, the ship symbolized Dutch global trade 'through which we enjoy the profit and pleasure of faraway countries'. ${ }^{41}$

To expound this message of imperial prosperity, the procession continued to the Oudezijds Voorburgwal, where another triumphal arch allegorically revealed Maria de' Medici's entrance on a triumphal carriage pulled by four lions. Guised as Berecynthia, the Roman Cybele that in the Augustan tradition was considered the protecting Magna Mater of empire, she is received by the personification of Amsterdam, seconded 
by four figures that represent the four continents. Significantly, the scene is crowned with the phrase Laeta deum partu ('Happy in a progeny of gods'), taken from a passage in Virgil's Aeneid that celebrates the global destiny of the Roman Empire. ${ }^{42}$ For all its humanist studiousness, the message of the arch is clear: Maria de' Medici honours with her divine presence the imperial metropolis of Amsterdam - the new Rome.

But Amsterdam was a particular incarnation of Rome, the heart of an empire not built by legionnaires, but by trade. Passing through the arch, Maria de' Medici reached the Oost-Indisch Huis, the headquarters of the Amsterdam chamber of the VOC, where she received a warm welcome in the boardroom, decorated with paintings of Dutch colonial outposts in Asia and exhibitions of weapons, silk, spices and other trading goods from the Dutch empire. A sumptuous banquet completed the scene, with dishes and ingredients from all over the world-meant to give Maria de' Medici the impression 'she was the guest of Indians, Moluccans, Persians, Arabs, Japanese and Chinese'. Amsterdam was thus turned into a global village, the centre of a multicultural world allegedly created by cooperative commerce. Barlaeus did admit that the VOC, apart from being a commercial company, had evolved into a warlike sovereign, 'performing and acting in ways that do not differ much from those of great Rulers'. ${ }^{43}$ For Barlaeus, the Company and the Republic basically coalesced. When Maria de' Medici visited the WIC headquarters on the other side of town, he stated that the VOC and WIC together formed a strong foundation for the Dutch Republic 'to spread its empire wherever the Sun is shining'. ${ }^{44}$

This grandiloquent expression of imperial self-esteem, hailing the Dutch empire as a new Rome where the sun never sets, arguably formed the culmination of humanist imperialism in the Dutch Republic - indeed, the single most manifest expression of empire (Barlaeus uses the term imperium) in the seventeenth century. It was also widely disseminated, for Barlaeus' celebratory text, printed in a lofty Latin edition, was subsequently translated into Dutch and French. Moreover, Barlaeus continued his imperialist fervour a decade later in his famous treatise on Johan Maurits van Nassau Siegen in Brazil. ${ }^{45}$ Yet Barlaeus' outspoken imperializing tone continued to highlight the commercial nature of the Dutch empire, allegedly not based on territorial conquests but on the insatiable lust for profit. After the loss of Brazil in 1654 and the stagnation of VOC expansion in Asia, this core element of the Dutch imperial narrative was intensified in the further monumentalization of Amsterdam as a commercial imperial metropolis. 
By far the most prominent illustration of this process is the Amsterdam Town Hall, inaugurated in 1655. The design and decorative scheme of this magnificent building merges different iconographical and allegorical references to Biblical and Roman antiquity under the general claim that Amsterdam should be considered the centre of the world, if not the universe. ${ }^{46}$ Most prominently, the two façades on either side of the classical building give a remarkable synopsis of the Dutch imperial self-image, carved into stone and visible to all. The façade at Dam Square is crowned by a bronze statue of Peace, under which a pediment shows Amsterdam ruling the seas. The pediment on the other side contains a personification of Trade resting on the globe while the four continents pay tribute. Inside of the building, on the floor of the central hall, two large marble maps reveal the Western and Eastern hemisphere and the latest Dutch naval campaigns at the end of the world ${ }^{47}$ In the Town Hall, Amsterdam's citizens thus literally trod the globe.

The same self-confident message of global domination, trade and prosperity spread throughout the city in the years around 1660. On their way from Dam Square towards the VOC headquarters, citizens and visitors first encountered the stock exchange, the financial heart of the Republic, and then the new building of the Amsterdam Admiralty, the organization for maritime control that played an important role in Dutch imperial policy. Its classical façade from 1662, clearly inspired by the Town Hall, was crowned with a pediment that shows the Dutch lion protecting Holland, flanked by Lady Justice, the god Mars and the sea god Neptune. In the same year, the boardroom in the VOC headquarters around the corner was embellished with a new series of paintings portraying important places for Dutch colonial trade in Asia, including Canton in China and Ayuthaya in Thailand, where the VOC held trading privileges, Cochin and Cananor, two recently conquered cities in India, and Banda Neira in the Moluccas, the location of Coen's notorious genocide from 1621 (now being portrayed as a well-ordered and serene colonial outpost). ${ }^{48}$ The most prominent painting, placed above the boardroom's chimney, depicted the centre of the Dutch empire in Asia: Batavia. Significantly, the artist, Andries Beeckman, took a viewpoint outside of Batavia's fortress, capturing an apparently peaceful urban scene in which the different cultures of the colonial city happily mingle and exchange goods. The setting of a cheerful and prosperous colonial order of intercultural cooperation, set against the backdrop of an imposing fortress and exotic palm trees, perfectly fitted the imperial illusions of the VOC board. ${ }^{49}$ 
Amsterdam's imperial self-representation concluded in the city's harbour with the construction of two colossal classical buildings, both designed by the city's chief architect Daniel Stalpaert. ${ }^{50}$ The first building, placed at a strategic location overlooking the harbour in 1655, served as the Admiralty's maritime arsenal; the second, an enormous construction from 1665, contained the Oost-Indisch Magazijn, the warehouses of the VOC. ${ }^{11}$ Erected in a monumental and imposing style meant to imitate Roman antiquity, these two buildings made a decisive impact on Amsterdam's urban outlook. Indeed, when another scion of the Medici family, Cosimo III of Tuscany, visited Amsterdam in 1668, the very first buildings he visited were those belonging to the VOC and the Admiralty. ${ }^{52}$ Some seventy years after the onset of Dutch colonial expansion, Amsterdam had been turned into an imperial metropolis that could not only easily compete with Renaissance Florence but also with the colonial capitals of Paris, London, Madrid and Lisbon. But unlike the Louvre, Whitehall, the Buen Retiro or the Paço da Ribeira, the palaces that represented Amsterdam's imperial might were not connected to a ruling monarchy proud of its victories on the battlefield, but to a republican elite that celebrated the exploits of global commercial enterprise. ${ }^{53}$

\section{Empire Is a Lady: Celebrating the Company-Republic}

In 1702, on the occasion of the VOC centenary, Amsterdam's imperial self-image was aptly epitomized in a classicist painting made by Nicolaas Verkolje for the Amsterdam Chamber of the VOC (Image 3.2). ${ }^{54}$ It shows a female representation of the Company, dressed in full armour and seated on the throne of empire, flanked by representations of navigation and trade. While two putti empty a cornucopia of Asian spices, a ship sets sail beyond the Pillars of Hercules, aiming for the Orient. The painting revisited many of the iconographical elements that had become staple images of Dutch imperialism in seventeenth-century Amsterdam, from the 1606 harpsichord to the Town Hall façade. In this tradition, the classical depiction of empire as an enthroned woman was given a decisive commercial and maritime twist with the claim that the Dutch had gone beyond the limits of the ancient world to trade in exotic spices.

At this moment, by the start of the eighteenth century, Dutch power in the Americas had subsided while the VOC in Asia essentially sought to consolidate its sovereign control over key areas and to develop existing trading networks without further territorial expansion. As a result, as 


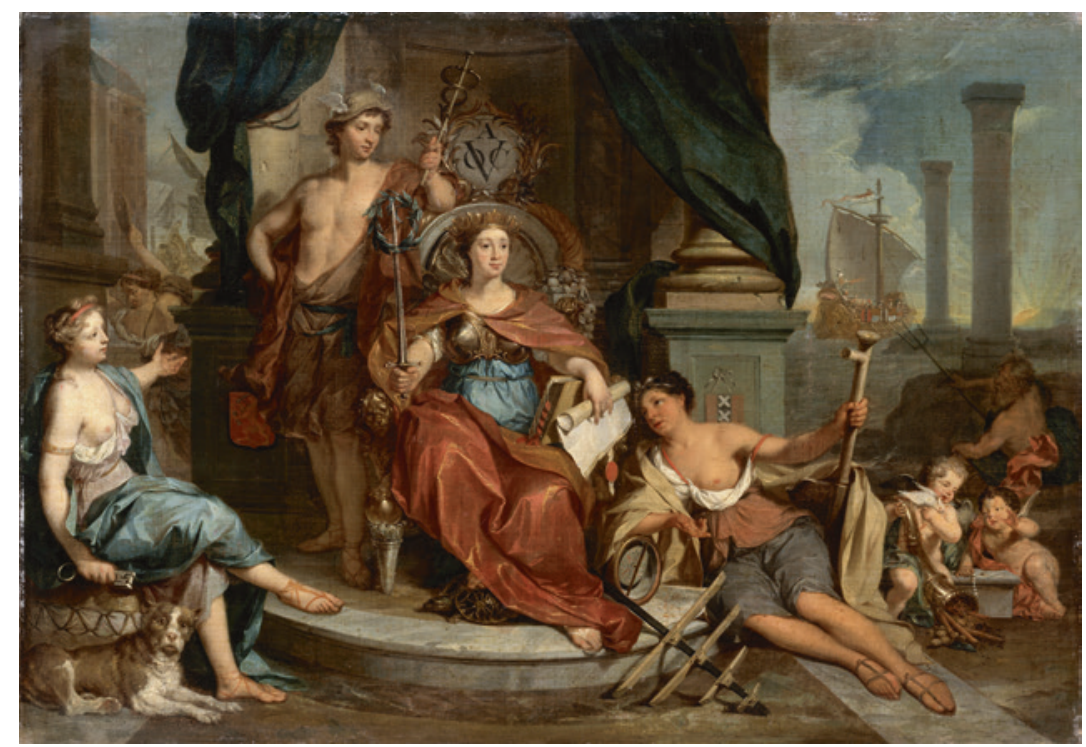

Image 3.2 Nicolaas Verkolje, Apotheosis of the Dutch East India Company. Allegory of the Amsterdam Chamber of Commerce of the VOC, c. 1702. Rijksmuseum, Amsterdam

Benjamin Schmidt argues, Dutch publications of the period increasingly emphasized the continental European perspective of empire, gradually eliding the Dutch role as a colonial actor. ${ }^{55}$ The very notion of a 'Dutch empire', which had only briefly surfaced in the work of Barlaeus around 1640, was never developed into a straightforward ideological concept. Nonetheless, the humanist idea of a specifically commercial empire, created around 1600, continued to dominate the representation of Dutch imperial power throughout the first half of the eighteenth century. Indeed, an honorary medal struck on the occasion of the VOC centenary, again showing a female imperial figure and a ship that sails beyond the Pillars of Hercules, is framed with the message In altera saecula pergo, 'I go on in another century'. ${ }^{56}$ This self-assured expression of continuing VOC power eventually evolved into a widespread iconographical celebration of the Dutch Company-Republic as a successful commercial empire, publicized to national and international audiences at the height of the Enlightenment. 
One of the leading figures in the development of this iconographical celebration was Bernard Picart, the French engraver and protestant convert who made a successful career in Amsterdam. Apart from his ground-breaking engravings on global religious diversity for the multi-volume Cérémonies et contumes religieuses de tous les peuples du monde, Picart also provided elaborate illustrations for a series of works on Dutch and general history. ${ }^{57}$ First, in 1722, he made the noteworthy frontispiece to Histoire des Provinces-Unies des Pays-Bas, one of the final works of Jean Le Clerc, the controversial Swiss theologian who had also migrated to Amsterdam where he became a leading Enlightenment scholar. This treatise on the history of the Dutch Republic, published in three volumes in Amsterdam between 1723 and 1728, opens with Picart's full-page allegory which is clearly indebted to the traditional representations of the Dutch commercial empire: a seated woman, protected by a lion and flanked by personifications of Religion, Liberty, Peace, Navigation, Trade, Fortune and Abundance, receives the treasures from America, Africa and Asia, against the background of a sailing fleet (Image 3.3). ${ }^{58}$ For Picart, the Dutch Republic could be epitomized as a global commercial power whose reign was based on freedom and international exchange.

A couple of years later, Picart further elaborated this theme with an illustration for a massive Dutch treatise on world history, authored by Geerlof Suikers and published posthumously in five volumes between 1721 and 1728 by the leading Amsterdam printing house of the Wetstein family. For the volume dealing with the sixteenth and early seventeenth century, dedicated by the Wetsteins to two Amsterdam burgomasters and Company directors, Picart made an engraving which depicts two female representations of the VOC and WIC. Once again, these figures are accompanied by personifications of Liberty and Trade, together with Lady Justice and a putto holding a Roman fasces, the emblem of imperium. With the dominating façade of the Amsterdam Town Hall in the background, different people who represent the non-European world provide an array of exotic goods, including chinaware and a small statue of Buddha. In the dedicatory text that accompanies the engraving, the Wetsteins explained it meant to show the importance of 'the Companies for the expansion of our patriots' trade to where the sun rises and sets'. ${ }^{59}$ The global reach of the VOC and WIC was thus connected to notions of urban patriotism and mercantile pride. 


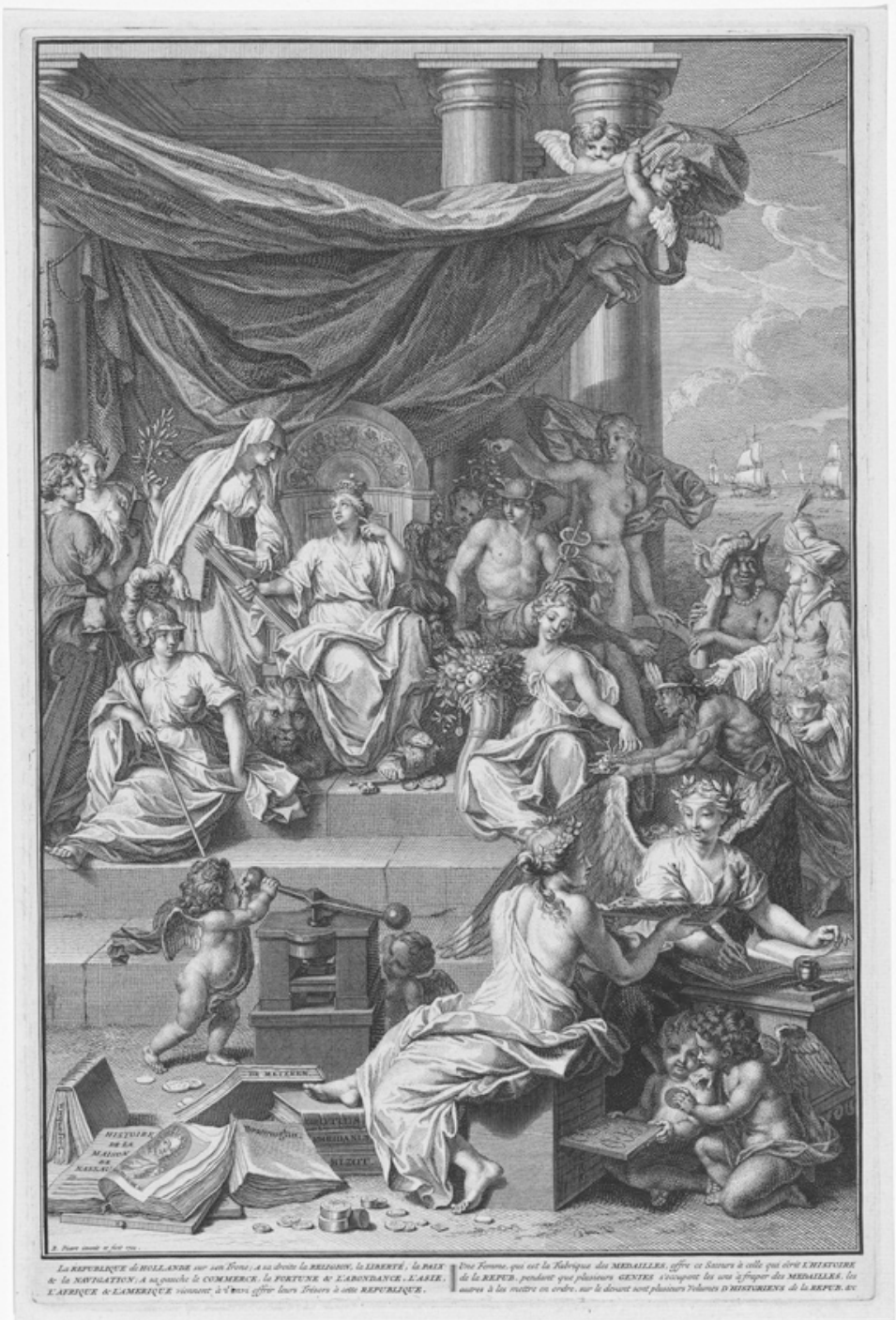

RP-P. 0B-51.557

Image 3.3 Bernard Picart, frontispiece to Jean Le Clerc, Histoire des ProvincesUnies des Pays-Bas, vol. 1 (Amsterdam: François L'Honoré and Zacharias Chatelain (II), 1723) 
Yet this image of a local-global commercial empire was not only intended for Dutch readers but also for an international audience. In 1730, Picart made a third engraving that combined the elements of his first two representations of the Dutch empire, now as the frontispiece for a French treatise on the political and economic situation of the Dutch Republic. This image shows three female figures together: the Dutch Republic in the middle, flanked by the VOC and WIC. Religion and Trade admire the scene, Neptune resigns 'the empire of the sea' to the Republic, and a putto unveils a map of 'the world where she extends her commerce'. ${ }^{60}$ The Dutch Republic and the two companies for colonial trade are merged into a trinity of maritime commercial imperialism.

Picart's engravings form the context to arguably the most important depiction of the early-modern Dutch empire: the lavish frontispiece to the multi-volume treatise by François Valentyn, who had served as a Dutch minister in different areas in Southeast Asia before writing an extensive historical, geographical and ethnographical overview of the areas where the VOC was active. The title of Valentyn's famous work, published between 1724 and 1726, prominently mentions that it gives an analysis of Nederlands mogentheyd or 'Dutch authority' in the East Indies - the only contemporary treatise to use this explicit conception of Dutch colonial power. ${ }^{61}$ This imperial claim is exemplified by the frontispiece, designed by the Amsterdam artist Gerard Melder and engraved by Andries van Buysen (Image 3.4). Clearly modelled after Picart's allegory of the Dutch Republic from 1722, the frontispiece shows a crowned woman seated on a throne, with the acronym VOC embroidered on her breast. This is Lady VOC, protected by the Dutch lion and with her feet placed upon a cornucopia and a helm, a bundle of arrows, and Mercury's staff - the insignia of navigation, concord and commerce. The personification of Time unveils the globe, next to the figure of Liberty who holds her symbol, a Phrygian hat, above Lady VOC. The naked truth, waving a palm leaf, pulls away a curtain that reveals an oriental scene, while Fortune blows her trumpet in the skies. Never before was the Dutch empire visualized so powerfully.

Compared to Picart's allegory from 1722, the crucial change in Valentyn's frontispiece is that Lady VOC has literally taken the place of the Dutch Republic, as an illustration of the interchangeability of Company and Republic. Following the iconographical tradition of the four continents paying tribute, the Company-Republic is presented as the mistress of the world who becomes rich through global exchange, 


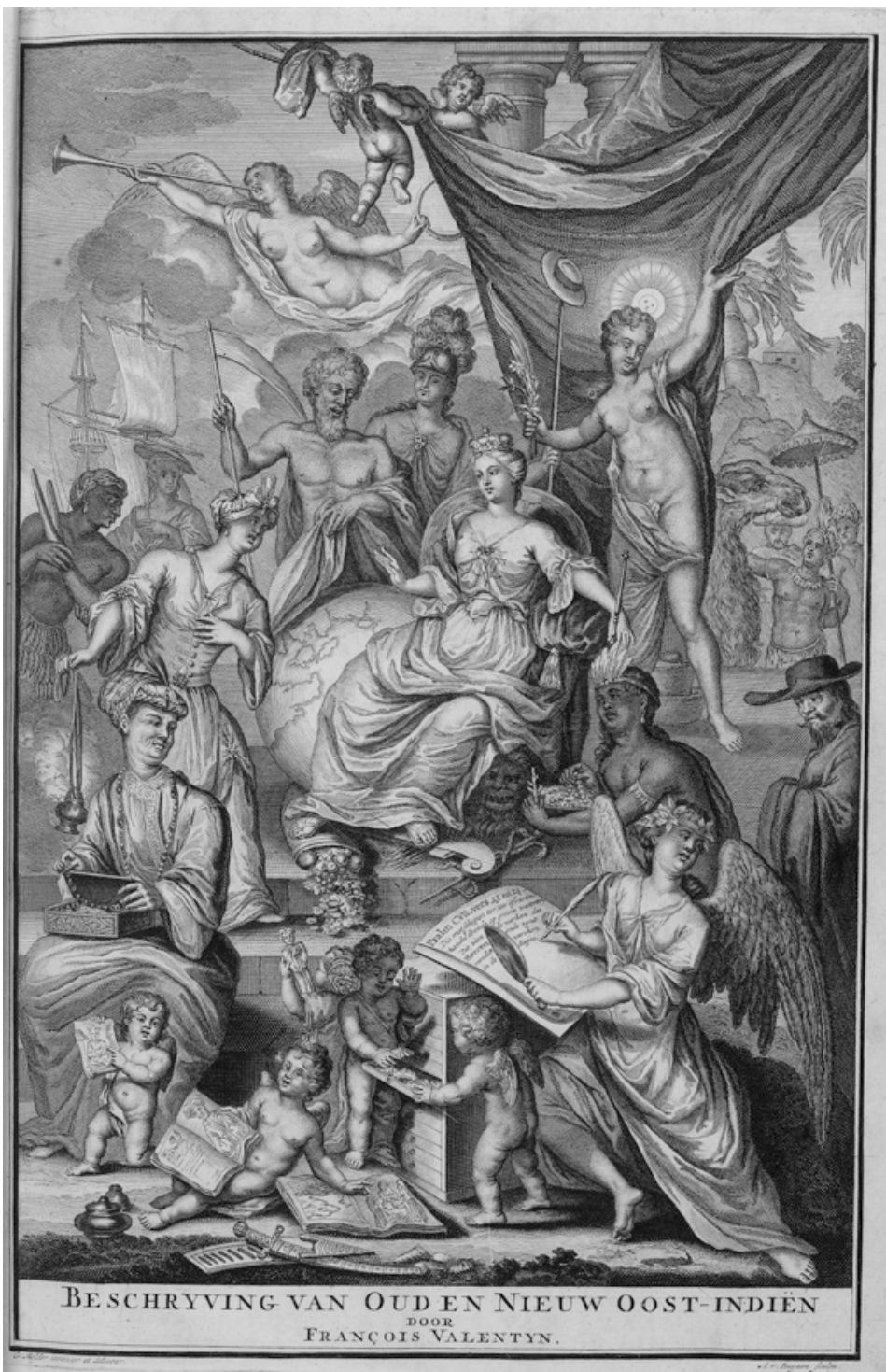

Image 3.4 Andries van Buysen after Gerard Melder, frontispiece to François Valentyn, Oud en Nieuw Oost-Indiën, vervattende een naaukeurige en uitvoerige verhandelinge van Nederlands mogentheyd in die gewesten, vol. 1 (Dordrecht: Johannes van Braam; Amsterdam: Gerard onder de Linden, 1724) 
receiving the luxury produce from Africa, Asia and America, while Europe observes the scene in front of a ship. Another element of the frontispiece is also slightly adapted from Picart's 1722 image: the angel of History in the foreground, who writes the letters of a psalm while putti open a cabinet filled with images and artefacts of the Orient. The Biblical verses written by the angel are from Psalm 107:23-24: 'They that go down to the sea in ships, that do business in great waters; These see the works of the Lord, and his wonders in the deep'. This Biblical message, which was often used in the early Enlightenment to claim the religious significance of gathering empirical knowledge, clearly referred to Valentyn's own career as a minister who turned into a scholar, combining godly with scientific pursuits. This reference to Valentyn's own persona is embodied by the dark figure on the right, a man in an oriental dress who represents the author himself: the middleman between the empire of the VOC and its immortalization in the book of history. ${ }^{62}$

The representation of the Dutch empire as a powerful CompanyRepublic remained en vogue for the next couple of decades, reappearing for example in 1739 as the frontispiece to a work on Dutch history by the prominent historian Jan Wagenaar, ${ }^{63}$ in 1740 as the frontispiece to a long colonialist poem on Batavia by the Amsterdam merchant and playwright Jan de Marre, ${ }^{64}$ and in the 1750s as an Allegory of the VOC, engraved by the designer Simon Fokke. ${ }^{65}$

The iconographical strength of this portrayal of commercial empire is shown by the fact it was also employed in eighteenth-century depictions of the British Empire. For example, the ceiling of the Upper-Hall at Greenwhich Hospital, painted by Sir James Thornhill between 1718 and 1725, shows a grand scene that centres upon Queen Anne, with 'the four continents admiring our Maritime Power'. ${ }^{66}$ In 1778, the VenetianGreek artist Spiridione Roma continued this theme in his allegorical ceiling piece for the East India House in London, titled The East Offering its Riches to Brittania. ${ }^{67}$ In these cases, the central female figure explicitly represents Britain as such, either personified by the monarchy or in the guise of 'Britannia'. Indeed, in the 1730s and 1740s the conception of a 'British Empire' increasingly gained momentum, perhaps best epitomized by the patriotic song 'Rule, Brittania!' from $1740 .{ }^{68}$

In the Dutch Republic, however, this amalgamation between empire and nation-state did not materialize. In the absence of a monarchical figure to represent the unity of nation and empire, the Dutch empire could only be embodied by the figure of the Company-Republic, based upon 
corporate and local visions of empire developed over more than a century, especially in the context of the VOC and the city of Amsterdam. Although the actual colonial policies of this Company-Republic differed little from those of other imperial powers, the Dutch narrative of empire remained firmly based upon the notion construed around 1600 of a purely commercial enterprise of profit-seeking for the common good. As a result, the concept of a 'Dutch empire' never became a comprehensive ideological construct.

\section{Conclusion}

The visions of commercial empire that were created and disseminated from 1600 onwards, permeated early-modern Dutch political culture, from the foundational 'Batavian myth' to the bookshops of the Enlightenment. In a variety of public media, including written documents such as diplomatic correspondence and the official VOC charter, visual representations such as the paintings in the VOC headquarters and Picart's frontispieces, and urban architecture such as the triumphal arches for Maria de' Medici and the Amsterdam Town Hall, the Dutch empire was presented as a benign commercial enterprise based upon global cooperation and prosperity.

Foreign observers and competitors were not easily deluded by this narrative. In 1682, for example, the Court of Committees of the EIC in London warned an embassy from the Javanese sultanate of Banten that the Dutch sought 'Empire of all those Countries, to the enslaving of many noble \& ancient Princes' ${ }^{69}$ This language of 'empire' was not adopted in the Dutch Republic itself. Protagonists in the development of the Dutch imperial self-image such as the humanist scholar Barlaeus or the colonial minister Valentyn occasionally used the terminology of imperium and its Dutch equivalent mogentheyd to describe and legitimize Dutch colonial rule. However, their phrasing did not imply a connected political system of the metropolis and its colonies (a 'Dutch empire'), but rather referred to the extent of Dutch power overseas (the imperium and authority 'of the Dutch'). Unlike in Britain, where a comparable narrative of commercial empire eventually evolved into the ideological conception of the 'British Empire', Dutch visions of empire remained within the framework established at the very onset of Dutch colonial expansion around 1600: that of a corporate enterprise seeking for profit, morally sanctioned by its conflation of mercantile self-interest with the common good. 
Arguably, this narrative of a Company-Republic had become so dominant over the course of the seventeenth and eighteenth centuries that it largely remained in place also after the demise of the Dutch Republic, the dissolution of the VOC, and the creation of an imperial nationstate' around $1800 .^{70}$ Still today, popular allusions in the Dutch public sphere to the early-modern colonial past often continue the enduring visions already created around 1600-most strikingly perhaps in the recurrent references to the alleged 'VOC-mentality' of commercial enterprise. One reason for this lasting dominance of the idea of an 'empire of riches' may be the long-term stability of its public incarnations from the seventeenth century, for example the Amsterdam Town Hall which still towers over Dam Square, the ceremonial centre of the Netherlands. But also less prominent traces of the early-modern imperial narrative remain in place as ties between past and present, such as the Admiralty's arsenal in Amsterdam harbour which is now the National Maritime Museum, visibly celebrating the country's colonial history with a large replica of an eighteenth-century East Indiaman, or the boardroom of the VOC headquarters, which has been reconstructed to its design from the 1660s and now serves as a lecture hall for history students of the University of Amsterdam. Recent interventions in the public debate have started to expose this continuous linkage between the colonial past and the postcolonial present, for example addressing the predominantly positive presentation of colonial objects and paintings in the collection of the Rijksmuseum. ${ }^{71}$ To understand why such uncritical attitudes to the Dutch empire remain entrenched in contemporary society, a first step is to realize that they go back as far as the origins of the Dutch empire itself.

\section{Notes}

1. Benjamin Schmidt, Innocence Abroad: The Dutch Imagination and the New World, 1570-1670 (Cambridge: Cambridge University Press, 2001). See also for practical implications in colonial practice, Mark Meuwese, Brothers in Arms, Partners in Trade: Dutch-Indigenous Alliances in the Atlantic World, 1595-1674 (Leiden: Brill, 2011); and for the Dutch in Asia: Martine van Ittersum, Profit and Principle: Hugo Grotius, Natural Rights Theories and the Rise of Dutch Power in the East Indies (15951615) (Leiden: Brill, 2006).

2. See the preceding chapter in this volume. 
3. The dominant interpretation of early-modern republicanism is presented in Quentin Skinner, Liberty Before Liberalism (Cambridge: Cambridge University Press, 1998).

4. On the British case, see David Armitage, The Ideological Origins of the British Empire (Cambridge: Cambridge University Press, 2000).

5. The persistent claims in recent historiography concerning the 'exceptional' nature of Dutch imperialism are discussed in Chapter 5 of this volume by Jennifer Foray.

6. I first explored the concept of a Dutch 'republican empire' in Arthur Weststeijn, 'Republican Empire: Colonialism, Commerce, and Corruption in the Dutch Golden Age,' Renaissance Studies 26 (2012): 491-509.

7. Simon Schama, The Embarassment of Riches: An Interpretation of Dutch Culture in the Golden Age (New York: Alfred A. Knopf, 1987).

8. Andrew Fitzmaurice, Humanism and America: An Intellectual History of English Colonisation, 1500-1625 (Cambridge: Cambridge University Press, 2003); David A. Lupher, Romans in a New World: Classical Models in Sixteenth-Century Spanish America (Ann Arbor: The University of Michigan Press, 2003); and Sabine MacCormack, On the Wings of Time: Rome, the Incas, Spain, and Peru (Princeton and Oxford: Princeton University Press, 2007).

9. See e.g. Felix Driver and David Gilbert, Imperial Cities: Landscape, Display and Identity (Manchester: Manchester University Press, 2003); Catherine Hall and Sonya O. Rose, At Home with the Empire: Metropolitan Culture and the Imperial World (Cambridge: Cambridge University Press, 2006); and John M. MacKenzie, ed., European Empires and the People: Popular Responses to Imperialism in France, Britain, the Netherlands, Belgium, Germany and Italy (Manchester: Manchester University Press, 2011).

10. Cf. Armitage, Ideological Origins; Peter J. Cain and Anthony G. Hopkins, 'Gentlemanly Capitalism and British Expansion Overseas I: The Old Colonial System, 1688-1850,' Economic History Review 39, no. 4 (1986): 501-525; Andrew Fitzmaurice, 'The Commercial Ideology of Colonization in Jacobean England: Robert Johnson, Giovanni Botero, and the Pursuit of Greatness,' The William and Mary Quarterly 64, no. 4 (2007): 791-820.

11. Cf. Daniel Immerwahr, How to Hide an Empire: A History of the Greater United States (New York: Farrar, Strauss \& Giroux, 2019).

12. Quoted (translation slightly altered) from Arnoud Vrolijk, 'Scaliger and the Dutch Expansion in Asia: An Arabic Translation for an Early Voyage to the East Indies (1600), Journal of the Warburg and Courtauld Institutes 78 (2015): 277-309; translation on 309. The letter is held in the Oriental collections of Leiden University Library, MS Or. 1365(3). 
I am very grateful to Arnoud Vrolijk for his help in the interpretation of the text.

13. For further background, see Romain Bertrand, L'histoire à parts egales: Récits d'une encontre Orient-Occident (XVIe-XVIIe siècle) (Paris: Seuil, 2011 ); cf. Arthur Weststeijn, 'Provincializing Grotius: International Law and Empire in a Seventeenth-Century Malay Mirror', in International Law and Empire: Historical Explorations, ed. Martti Koskenniemi, Walter Rech, and Manuel Jiménez Fonseca (Oxford: Oxford University Press, 2017), 21-38.

14. The Hague, Koninklijk Huisarchief MS KHA 13XII-B-2. See Vrolijk, 'Scaliger's Arabic Patent,' 288.

15. On Scaliger, see especially the extensive work by Anthony Grafton, Joseph Scaliger: A Study in the History of Classical Scholarship, 2 vols. (Oxford: Clarendon Press, 1983-1993).

16. This patent letter was translated and printed by Franciscus Raphelengius, professor of Hebrew at Leiden University until his death in 1597. See Herman de Leeuw, 'The First Dutch-Indonesian Treaty: A Rediscovered Arabic Translation by Franciscus Raphelengius,' Manuscripts of the Middle East IV (1989): 115-122.

17. Thesaurus linguae Arabicae, Leiden University Library MS Or. 212, fols. $78 \mathrm{~b}$ and $14 \mathrm{lb}$. Cf. also the Portuguese version of the patent which uses the phrasing 'nao somente honesto, mas proveitoso': Hendrik Hoogenberk, De rechtsvoorschriften voor de vaart op Oost-Indië, 15951620 (Utrecht: Kemink, 1940), appendix III, 232-233.

18. Cicero, De officiis, III.12-14. For the longstanding impact of Ciceronian ethics on imperial thinking, see Peter N. Miller, Defining the Common Good: Empire, Religion and Philosophy in Eighteenth-Century Britain (Cambridge University Press, 1994).

19. Officia Ciceronis, leerende wat yeghelijck in allen staten behoort te doen, bescreuen int Latijn, trans. Dirck Coornhert (Haarlem: Jan van Zuren, $1561)$.

20. Dirck Coornhert, De Coopman. Aanwysende d'oprechte conste om Christelyck ende met eenen gelycken moede in 't winnen ende verliesen coophandel te dryven, ed. S. van der Woude (Amsterdam: Corvey, 1969).

21. Resoluties van de Staten van Holland, 15-21 May 1601, quoted in J.K.J. de Jonge, ed., De opkomst van het Nederlandsch gezag in Oost-Indië (1595-1610), 13 vols. (The Hague: Nijhoff, 1862-1895), vol. 1, 138: 'niet alleen eerlijk en dienstig, maar tot den conservatie van den voors. handel nodig.' On the establishment of the VOC, see Oscar Gelderblom, Abe de Jong, and Joost Jonker, 'The Formative Years of the Modern Corporation: The Dutch East India Company, 1602-1623,' Journal of Economic History 74 (2013): 1050-1076. 
22. For a comparative analysis of the Dutch and English East India Companies, see Adam Clulow and Tristan Mostert, eds., The Dutch and English East India Companies: Diplomacy, Trade and Violence in Early Modern Asia (Amsterdam: Amsterdam University Press, 2018).

23. Quoted in De Jonge, ed., Opkomst, vol. 1, 146: 'eerlyck, dienstelyck en proffytelyck.'

24. VOC Charter (1602), from: https://www.vocsite.nl/geschiedenis/octrooi. html: 'dat eerlijk, dienstig en profytig, niet alleen voor de vereenigde Landen, maar ook voor allen den genen, die deze loffelyke handeling by de hand genomen hadden, ende daar inne waren participerende, zoude wezen, dat de zelve Compagnie vereenigt, ende de voorschreve handeling onder een vaste ende zekere eenigheid, ordre, ende politie, zoude mogen gemeen gehouden, gedreven, ende vermeerdert werden, voor alle de ingezetenen der vereenigde Landen, die daar in zouden believen te participeren.'

25. Hugo Grotius, De jure praedae commentarius, ed. H.G. Hamaker (The Hague: Nijhoff, 1868), esp. Chapters XIV and XV. On Grotius' reading of Cicero, see the expert analysis in Benjamin Straumann, Roman Law in the State of Nature: The Classical Foundations of Hugo Grotius' Natural Law (Cambridge University Press, 2015). On the concrete colonial background, see Van Ittersum, Profit and Principle; and Peter Borschberg, Hugo Grotius, the Portuguese and Free Trade in the East Indies (Singapore: NUS Press, 2011).

26. Quoted from Hugo Grotius, Commentary on the Law of Prize and Booty, ed. Martine van Ittersum (Indianapolis: Liberty Fund, 2006), 247-248.

27. Cf. Coen Maas, "Non erubescat Hollandia”: Classical Embarrassment of Riches and the Construction of Local History in Hadrianus Junius' Batavia,' in The Quest for an Appropriate Past in Literature, Art and Architecture, ed. Karl Enenkel and Koen Ottenheym (Leiden: Brill, 2019), 361-382. On the origins of the Batavian Myth, see Karl Enenkel and Koen Ottenheym, Oudheid als ambitie. De zoektocht naar een passend verleden, 1400-1700 (Nijmegen: Vantilt, 2017), 137-166.

28. Hugo Grotius, Parallelon rerumpublicarum. Liber tertius: de moribus ingenioque populorum Atheniensium, Romanorum, Batavorum, ed. Johan Meerman, 4 vols. (Haarlem, 1801-1803), vol. 3: 9, 59. For further background to Grotius' argumentation, see Arthur Weststeijn, 'Commonwealths for Preservation and Increase: Ancient Rome in Venice and the Dutch Republic,' in Ancient Models in the Early Modern Republican Imagination, ed. Wyger Velema and Arthur Weststeijn (Leiden: Brill, 2017), 62-85.

29. Coen to patria, 27 December 1614, in Jan Pietersz. Coen, Bescheiden omtrent zijn verblijf in Indië, ed. H.T. Colenbrander (The Hague: Nijhoff, 1919), vol. 1, 98: 'den handel sonder d'oorloge, noch d'oorloge sonder den handel nyet gemainteneert connen werden'. 
30. Amsterdam Chamber to Coen, 14 April 1622, in Coen, Bescheiden, vol. 4, 539: 'dat ten onsen aensien (als coopluyden sijnde) die d'eere heeft, die wel ende niemant gewelt oft onrecht doende, 't proffijt heeft, 't welck buyten de consideratien van princen ende grote potentaten.'

31. Cf. Fitzmaurice, 'Commercial Ideology of Colonization,' and idem, 'The Dutch Empire in Intellectual History,' BMGN-Low Countries Historical Review 132, no. 2 (2007): 97-109.

32. See Schmidt, Innocence Abroad, 176-183, 244-245; Willem Frijhoff, Fulfilling God's Mission: The Two Worlds of Dominie Everardus Bogardus, 1607-1647 (Leiden: Brill, 2007), 290-293.

33. C.R. Boxer, The Dutch Seaborne Empire, 1600-1800 (London: Hutchinson, 1977), 113.

34. Pauline Lunsingh-Scheurleer, 'Uitwisseling van staatsieportretten op Ceylon in 1602,' in Aan de overkant: Ontmoetingen in dienst van de VOC en WIC, ed. Lodewijk Wagenaar (Leiden: Leiden University Press, 2015), 165-197.

35. Quoted in Adam Clulow, The Company and the Shogun: The Dutch Encounter with Tokugawa Japan (New York: Columbia University Press, 2014), 67-69.

36. Wim Klooster, The Dutch Moment: War, Trade, and Settlement in the Seventeenth-Century Atlantic World (Cornell University Press, 2016); See also Alexander Bick, Governing the Free Sea: The Dutch West India Company and Commercial Politics, 1618-1645 (PhD dissertation, Princeton University, 2012); and Pepijn Brandon and Karwan FatahBlack, "For the Reputation and Respectability of the State": Trade, the Imperial State, Unfree Labor, and Empire in the Dutch Atlantic,' in Building the Atlantic Empires: Unfree Labor and Imperial States in the Political Economy of Capitalism, ca. 1500-1914, ed. John Donoghue and Evelyn Jennings (Leiden: Brill, 2015), 84-108.

37. Michiel van Groesen, Amsterdam's Atlantic: Print Culture and the Making of Dutch Brazil (Philadelphia: Pennsylvania Press, 2017).

38. See Elmer Kolfin, 'Omphalos Mundi: The Pictorial Tradition of the Theme of Amsterdam and the Four Continents, Circa 1600-1665, in Aemulatio: Imitation, Emulation and Invention in Netherlandish Art from 1500 to 1800. Essays in Honor of Eric Jan Sluijter, ed. Anton Boschloo et al. (Zwolle: Waanders, 2011), 383-392; quote on 385.

39. On Amsterdam's urban development and self-presentation in the seventeenth century, see the useful overview in Marjolein 't Hart, 'The Glorious City: Monumentalism and Public Space in Seventeenth-Century Amsterdam,' in Urban Achievement in Early Modern Europe: Golden Ages in Antwerp, Amsterdam and London, ed. Patrick O'Brien et al. (Cambridge: Cambridge University Press, 2001), 128-150. 
40. See Caspar Barlaeus, Medicea hospes, sive descriptio publicae gratulationis, qua Serenissimam, Augustissimamque Reginam, Mariam de Medicis, excepit Senatus Populusque Amstelodamensis (Amsterdam: Blaeu 1638), translated into Dutch by Joost van den Vondel: Blyde inkomst der allerdoorluchtighste koninginne, Maria de Medicis, t'Amsterdam (Amsterdam: Blaeu, 1639). The displays are discussed in detail in D.P. Snoep, Praal en propaganda. Triumfalia in de Noordelijke Nederlanden in de $16^{e}$ en $17^{e}$ eeuw (Alphen aan de Rijn: Canaletto, 1975), 39-64; and Megan Blocksom, 'Procession, Pride and Politics in the Medicea Hospes (1638): A Dutch Festival Book for a French Queen,' Dutch Crossing 42, no. 1 (2018): 3-27. On Barlaeus' services for the Amsterdam elite, see also Caspar Barlaeus, The Wise Merchant, ed. Anna-Luna Post (Amsterdam: Amsterdam University Press, 2019).

41. Barlaeus, Medicea hospes, 14: 'His remotissimarum regionum lucris \& commodis fruimur.'

42. Virgil, Aeneid VI, 786.

43. Barlaeus, Medicea hospes, 30-33: 'denique ea agit perficitque quae à magnarum Potestatum conatibus non longè abscedunt [...] cum Indis se, Moluccensibus, Persis, Arabibus, Iaponensibus, Sinis convivari jucunda animi agitatione putabat.'

44. Barlaeus, Medicea hospes, 37: 'ut duabus Societatibus innixa Respublica, imperium cum Sole quaquaversum diffundat.'

45. The treatise is analysed in Weststeijn, 'Republican Empire,' and Idem, 'Machiavelli in Dutch Colonial Ideology. Caspar Barlaeus, Johan Maurits of Nassau, and the Imperial Prince,' Storia del Pensiero Politico 6, no. 2 (2017): 177-196.

46. For two recent interpretations, see Pieter Vlaardingerbroek, 'An Appropriated History: The Case of the Amsterdam Town Hall (1648-1667),' in The Quest for an Appropriate Past, ed. Enenkel and Ottenheym, 455-481; Arthur Weststeijn, 'Imperial Republics: Roman Imagery in Italian and Dutch Town Halls, c. 1300-1700,' in Renovatio, inventio, absentia imperii. From the Roman Empire to Contemporary Imperialism, ed. Wouter Bracke, Jan de Maeyer, and Jan Nelis (Leuven: Brepols, 2018), 93-116.

47. See Katharine Fremantle, The Baroque Town Hall of Amsterdam (Utrecht: Haentjes Dekker \& Gumbert, 1959), 169-188; Eymert-Jan Goossens, Het Amsterdams paleis. Schat van beitel en penseel (Amsterdam: Waanders, 2010), 33-45.

48. The paintings, now in the collection of the Amsterdam Rijksmuseum, are reproduced in Kees Zandvliet, Mapping for Money: Maps, Plans and Topographic Paintings and Their Role in Dutch Overseas Expansion During the 16th and 17th Centuries (Amsterdam: De Bataafsche Leeuw, 2002), 219-223. 
49. Beeckman's famous painting, also in the Rijksmuseum, is discussed in detail in Els M. Jacobs, 'Beeckman's Batavia,' in Schatkamer. Veertien opstellen over maritiem-historische onderwerpen aangeboden aan Leo $M$. Akveld, ed. S. de Meer et al. (Franeker: Van Wijnen, 2002), 101-113.

50. On Stalpaert, see Gea van Essen, 'Daniel Stalpaert (1615-1676) stadsarchitect van Amsterdam en de Amsterdamse stadsfabriek in de periode 1647 tot 1676,' Bulletin KNOB 99, no. 4 (2000): 101-120.

51. For an overview of VOC buildings in Amsterdam, see Roelof van Gelder and Lodewijk Wagenaar, Sporen van de Compagnie. De VOC in Nederland (Amsterdam: De Bataafsche Leeuw, 1988), 60-81. The classical architecture of the Admiralty's Arsenal is discussed in Sjoerd de Meer, 's Lands Zeemagazijn (Zutphen: Walburg Pers, 1994).

52. G.J. Hoogewerff, ed., De twee reizen van Cosimo de' Medici, prins van Toscane, door de Nederlanden (1667-1669). Journalen en documenten (Amsterdam: J. Müller, 1919).

53. On the imperial palaces of Italy, Spain, France and England, cf. Thomas Dandelet, The Renaissance of Empire in Early Modern Europe (Cambridge: Cambridge University Press, 2014).

54. Paul Knolle and Everhard Korthals Altes, eds., Nicolaas Verkolje (16731746). De fluwelen hand (Zwolle: Waanders, 2011), 88-89.

55. See the next chapter in this volume.

56. The medal is in the collection of the Amsterdam Rijksmuseum, object number NG-VG-1-1862. See also Femme Gaastra, Bewind en beleid bij de VOC. De financiële en commerciële politiek van de bewindhebbers, 16721702 (Zutphen: De Walburg Pers, 1989), 238-239.

57. Lynn Hunt, Margaret C. Jacob, and Wijnand Mijnhardt, The Book That Changed Europe: Picart \& Bernard's Religious Ceremonies of the World (Cambridge, MA: Harvard University Press, 2010). On Picart's Dutch context, see Inger Leemans, 'Picart's Dutch Connections: Family Trouble, the Amsterdam Theatre and the Business of Engraving,' in Bernard Picart and the First Global Vision on Religion, ed. M.C. Jacob, L. Hunt, and W. Mijnhardt (Los Angeles: Getty Research Institute, 2010), 35-58.

58. Jean le Clerc, Histoire des Provinces-Unies des Pays-Bas, depuis la naissance de la République (1560) jusqu'à la Paix d'Utrecht et le Traité de la Barriere conclu en 1716: avec les principales medailles et leur explication, 3 vols. (Amsterdam: Z. Chatelain, 1723-1728).

59. Geerlof Suikers and Isaac Verburg, Algemene kerkelyke en wereldlyke geschiedenissen des bekenden aardkloots, vol. 4 (Amsterdam: Gerard and Rudolf Wetstein, 1726), sig. 3v.: 'de Maatschappyen, tot uitbreiding van den koophandel onzer vaderlanderen, daar de zon op- en daar zy onder gaat.'

60. François Janiçon, Etat présent de la République des Provinces-unies et des pays qui en dépendent (The Hague: Van Duren, 1729): 'l'empire de la 
mer $[\ldots]$ du Monde ou elle étend son commerce.' The engraving is also included in the Dutch translation of 1731.

61. François Valentyn, Oud en Nieuw Oost-Indiën, vervattende een naaukeurige en nitvoerige verhandelinge van Nederlands mogentheyd in die gewesten, 5 vols. (Dordrecht: Johannes van Braam; Amsterdam: Gerard onder de Linden, 1724-1726). For analysis, see Jörg Fisch, Hollands Rubm in Asien: François Valentyns Vision des niederländischen Imperiums im 18. Jabrhundert (Wiesbaden: Steiner, 1986); R.R.F. Habiboe, Tot verheffing van mijne natie: het leven en werk van François Valentijn (1666-1727) (Franeker: Van Wijnen, 2004); and Siegfried Huigen, 'Antiquarian Ambonese. François Valentyn's Comparative Ethnography (1724),' in The Dutch Trading Companies as Knowledge Networks, ed. Siegfried Huigen, Jan de Jongh, and Elmer Kolfin (Leiden: Brill, 2010), 171-200.

62. See Siegfried Huigen, "De "Schryver" als Oosterling. Een interpretatie van de titelprent van Oud en Nieuw Oost-Indiën van François Valentyn,' Nieuw Letterkundig Magazijn 32 (2014): 10-18.

63. Jan Wagenaar, Hedendaagsche historie, of Tegenwoordige staat der Vereenigde Nederlanden (Amsterdam: Isaak Tirion, 1739).

64. Jan de Marre, Batavia, begrepen in zes boeken (Amsterdam: Adriaan Wor, $1740)$.

65. This undated etching can be found in the collection of the Rijkmuseum, object number RP-P-OB-50.839.

66. An Explanation of the Painting in the Royal Hospital at Greenwhich by Sir James Thornhill (London, 1730), 14; See also Armitage, Ideological Origins, 167-168.

67. It is now in the collection of the British Library, file name G70067-73.

68. See Armitage, Ideological Origins, 170-186.

69. Quoted in Philip J. Stern, The Company-State. Corporate Sovereignty and the Early Modern Foundations of the British Empire in India (Oxford: Oxford University Press, 2011), 70.

70. On this transformation, see Chapter 7 in this volume by René Koekkoek.

71. See e.g. Marieke Bloembergen and Martijn Eickhoff, 'Een klein land dat de wereld bestormt. Het nieuwe Rijksmuseum en het Nederlandse koloniale verleden,' BMGN-Low Countries Historical Review 129, no. I (2014): 156-169. Cf. also Gert Oostindie, Postkoloniale Beeldenstormen (Nijmegen: Vantilt, 2018) and the ensuing debate with Martijn Eickhoff and Barbara Henkes, published online at: https://www.historici.nl/wp-content/ uploads/2018/08/Henkes-Eickhoff-20-08-postkoloniale-beeldenstormen. pdf and https://www.historici.nl/wp-content/uploads/2018/08/ Oostindie-Dupliek-Daendels-2018.pdf. 
Open Access This chapter is licensed under the terms of the Creative Commons Attribution 4.0 International License (http://creativecommons.org/licenses/ by $/ 4.0 /$ ), which permits use, sharing, adaptation, distribution and reproduction in any medium or format, as long as you give appropriate credit to the original author(s) and the source, provide a link to the Creative Commons license and indicate if changes were made.

The images or other third party material in this chapter are included in the chapter's Creative Commons license, unless indicated otherwise in a credit line to the material. If material is not included in the chapter's Creative Commons license and your intended use is not permitted by statutory regulation or exceeds the permitted use, you will need to obtain permission directly from the copyright holder.

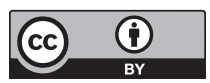

